\title{
Effect of the genetic group, production system and sex on the meat quality and sensory traits of beef from crossbred animals
}

\author{
R. T. Nassu ${ }^{1}$ • R. R. Tullio ${ }^{1}$ - A. Berndt ${ }^{1}$ - V. C. Francisco ${ }^{2}$ T. A. Diesel ${ }^{3}$. \\ M. M. Alencar ${ }^{1}$
}

Received: 11 May 2017 / Accepted: 30 May 2017 / Published online: 10 June 2017

(C) Springer Science+Business Media Dordrecht 2017

\begin{abstract}
The crossbreeding of two or more breeds from the Bos taurus and Bos indicus species is an alternative for obtaining high-quality meat from animals adapted to tropical climates. Quality and sensory attributes of beef, mainly its tenderness and flavour, are very important with regard to the consumer's point of view. This study aimed to evaluate the physico-chemical and sensory characteristics of crossbred young bulls and heifers, the offspring of Angus or Limousin bulls and $1 / 2$ Angus $+1 / 2$ Nellore or $1 / 2$ Simental $+1 / 2$ Nellore cows that were finished on feedlot or pasture. Meat quality traits $(\mathrm{pH}$, colour, cooking loss, water holding capacity and shear force) and sensory parameters (characteristic beef aroma/flavour intensity, strange aroma/flavour intensity, tenderness and juiciness descriptive attributes, flavour, texture (tenderness) and overall acceptance) were evaluated. The genetic group had an effect on the beef $\mathrm{pH}$, but it was not as relevant as the effect of the combination between the production system and the sex or genetic group, which affected many of the quality and sensory traits.
\end{abstract}

Keywords Acceptance $\cdot$ Bos taurus $\cdot$ Bos indicus $\cdot$

Descriptive analysis $\cdot$ Flavour $\cdot$ Tenderness

R. T. Nassu

renata.nassu@embrapa.br

1 Embrapa Pecuária Sudeste, Rodovia Washington Luiz, km 234, P.O. box 339, São Carlos, SP 13560-970, Brazil

2 Faculdade de Ciências Farmacêuticas (FCFAr), Universidade Estadual Paulista (UNESP), São Paulo, Brazil

3 Departamento de Zootecnia, Universidade do Estado de Santa Catarina - UDESC, Chapecó, SC, Brazil

\section{Introduction}

The use of specialized breeds and crossbreeding to produce meat associated with technologies such as ageing is a strategy that can be used to increase the productivity of production systems and improve meat quality. Sensory characteristics such as the tenderness, flavour and appearance are important to verify the consumers' acceptability and need to be addressed for meat quality control. Many factors are involved in beef sensory quality, and variations can be induced by production factors as the breed, age, and diet as well as technological factors such as the slaughter conditions, ageing time and cooking procedures (Bernard et al. 2007). Sensory analysis is an important tool to evaluate attributes that cannot be properly measured by objective methods, such as the aroma, flavour and texture (tenderness and juiciness), as human perception is more complete. Many studies have reported the effect of the production system (pasture- or feedlot-finished) or sex on meat quality (French et al. 2000; Varela et al. 2004; Realini et al. 2004; Moloney et al. 2008), and a few have evaluated the effect on beef eating quality (French et al. 2001). However, there is a lack of studies reporting the sensory characteristics and acceptance of crossbred animals and the effects of the genetic group, production system and sex on beef eating quality. This study aimed to evaluate meat quality traits and sensory characteristics of beef from crossbred animals composed of breeds adapted and non-adapted to tropical climate finished on feedlot or pasture.

\section{Materials and methods}

\section{Samples}

Beef samples from 225 young bulls and heifers, the offspring of Angus or Limousin bulls and $1 / 2$ Angus $+1 / 2$ Nellore or $1 / 2$ 
Simmental + 1/2 Nellore cows from Embrapa Pecuária Sudeste, São Carlos, Brazil, were evaluated. These animals were sired by seven bulls of each breed. The crossbred dams were contemporaneous, reared together, and the offspring of 22 bulls of each breed (Angus and Simmental) and of commercial Nellore cows of the same genetic basis. After weaning at 8 months of age, half of the animals were maintained at the feedlot in $30 \mathrm{~m}^{2}$ individual pens for 4.5 months and slaughtered at $419 \mathrm{~kg}$, on average. The other half were raised on pasture for 10 months and slaughtered at $450 \mathrm{~kg}$. The diet at the feedlot was changed from D1 to D2 when heifers and young bulls reached 330 and $380 \mathrm{~kg}$, respectively (Table 1). This experiment was conducted over 2 years. In the pasture, animals received 5-8 $\mathrm{kg}$ of corn silage plus $1 \mathrm{~kg}$ of supplement (S1) in the dry season as well as $3 \mathrm{~kg}$ of supplement (S2) in the wet season (Table 1). Animals were slaughtered when they reached a backfat thickness of approximately $5 \mathrm{~mm}$ estimated by ultrasound measurements. Animals were shipped the day before slaughter to a commercial abattoir and held overnight with access to water. Carcasses were chilled at $2{ }^{\circ} \mathrm{C}$ overnight for $24 \mathrm{~h}$. At $24 \mathrm{~h}$ after slaughter, $2.5 \mathrm{~cm}$ steaks were taken from the longissimus muscle of the left halfcarcass for quality ( $\mathrm{pH}$, water holding capacity, cooking loss, objective colour and shear force) and sensory (descriptive analysis and sensory acceptance) analyses.

\section{Meat quality analyses}

For objective colour evaluation, steaks were exposed to atmospheric oxygen for $30 \mathrm{~min}$ prior to the analyses, and CIE $\mathrm{L}^{*}$, $a^{*}$ and $b^{*}$ parameters were measured at three locations across the surface of the steaks using a MiniScan XE HunterLab colourimeter with Universal Software v. 4.10 (Hunter Associates Laboratory, Inc., Reston, VA, USA), illuminant D65 and a $10^{\circ}$ observer. The $\mathrm{pH}$ was then also measured at three locations across the surface using a Testo $\mathrm{pH}$ measuring instrument, model 230 (Testo AG, Lenzkirch, Germany). The

Table 1 Diet composition (\% dry matter)

\begin{tabular}{lrrrr}
\hline & $\mathrm{D} 1$ & $\mathrm{D} 2$ & $\mathrm{~S} 1$ & $\mathrm{~S} 2$ \\
\hline Corn silage & 68.0 & 50.0 & & \\
Ground corn grain & 12.0 & 32.8 & 48.0 & 65.0 \\
Wheat meal & 3.5 & 8.0 & 20.0 & \\
Soybean meal & 15.0 & 7.0 & 20.0 & 13.0 \\
Limestone & 0.5 & 0.7 & 4.0 & \\
Mineral supplement & 1.0 & 1.0 & 5.0 & 2.0 \\
Urea & & 0.5 & 3.0 & \\
Corn gluten & & & & 10.0 \\
Protected fat & & & & 10.0 \\
\hline
\end{tabular}

D1 feedlot diet 1,D2 feedlot diet 2, S1 pasture supplement in the dry period, $S 2$ pasture supplement in the wet period water holding capacity was obtained by the difference between the weights of a meat sample of approximately $2 \mathrm{~g}$ before and after it was submitted to a pressure of $10 \mathrm{kgf}$ for 5 min as described by Hamm (1986). For cooking loss and shear force measurements, the same steak of $2.5 \mathrm{~cm}$ thickness was weighed and cooked in a TC 06 Tedesco combined oven (Tedesco, Caxias do Sul, RS, Brazil) at $170{ }^{\circ} \mathrm{C}$ until the temperature at the centre of the sample reached $70{ }^{\circ} \mathrm{C}$, controlled by thermocouples linked to the FE-MUX software (Flyever, São Carlos, SP, Brazil). The samples were then cooled at room temperature and weighed again. The cooking loss was calculated by the difference between the weights before and after cooking and expressed as a percentage. These steaks were transferred to a cooler and held for $24 \mathrm{~h}$, after which, eight cores, $1.27 \mathrm{~cm}$ in diameter, were removed per steak parallel to the fibre grain. The peak shear force was determined on each core perpendicular to the fibre grain using a 1.016-mm Warner Bratzler probe in a TA.XT Plus Texture Analyser (200 $\mathrm{mm} \mathrm{min}^{-1}$ crosshead speed, $50 \mathrm{~kg}$ load cell, $40 \mathrm{~mm}$ distance, $10 \mathrm{~kg}$ calibration weight, Stable Micro Systems Ltd., Surrey, UK). The full peak shear force was recorded, and the maximum shear force was calculated as the average of the eight cores.

\section{Sensory analyses}

Five steaks from different animals of each combination of bull breed, cow genetic group, production system and sex were used for the descriptive sensory analyses. For sensory acceptance, a 30-cm piece of longissimus muscle was obtained from one animal representing each of those combinations and was cut into ten steaks. The day before the descriptive sensory analyses and acceptance sessions, previously frozen beef samples were placed in a refrigerator at $5{ }^{\circ} \mathrm{C}$ overnight. Beef samples for acceptance tests were treated with $1 \mathrm{~g}$ of salt; for descriptive analyses, they were unsalted. The following day (day of sensory analyses), steaks for descriptive sensory analyses were cooked in a TC 06 Tedesco combined oven (Tedesco, Caxias do Sul, RS, Brazil) at $170{ }^{\circ} \mathrm{C}$ until reaching an internal temperature of $75^{\circ} \mathrm{C}$. Steaks for acceptance tests were pan-fried with soybean oil until reaching the same previously mentioned temperature for descriptive analyses. Each steak was cut into $1.5 \mathrm{~cm}$ side cubes, wrapped in aluminium foil and maintained hot at $60{ }^{\circ} \mathrm{C}$ in glass recipients in a controlled temperature water bath. For sensory descriptive analyses, samples from five steaks from each combination were individually evaluated and were randomly assigned to a tenmember trained taste panel. The samples for each panellist were presented in a balanced design assigned by Fizz Software version 2.41 (Biosystemes, Couternon, France). Eight samples were evaluated per session. Attribute ratings were electronically collected using nine point descriptive scales for the beef characteristic aroma (BCA) $(1=$ extremely 
bland; 9 = extremely intense), beef characteristic flavour (BCF) $(1=$ extremely bland; 9 = extremely intense $)$, strange aroma $(\mathrm{SA})(1=$ extremely intense; $9=$ none $)$, strange flavour (SF) $(1=$ extremely intense; $9=$ none $)$ and tenderness (TE) $(1=$ extremely tough; $9=$ extremely tender). For sensory acceptance, 14 treatments were analysed, as it was not possible to collect samples of 2 of the 16 possible combinations. Samples of each combination were randomly assigned to 50 non-trained panellists divided into six different sessions when 2 or 3 treatments were analysed. The attribute ratings were collected using nine-point hedonic scales for flavour, texture and overall acceptance $(1=$ dislike extremely; $9=$ like extremely).

\section{Statistical analyses}

The experimental design was completely randomized, with the breed of the sire (BS), cow genetic group (CGG), sex (SEX), production system (SYS), year and interactions as fixed factors for quality and descriptive sensory analyses. As the cow genetic group was not significant for the studied parameters, it was removed from the model, and the genetic group of the animal (breed of sire $\times$ cow genetic group, GG) was considered. A mixed model was used to analyse the data. Means were compared by the Student Newman-Keuls (SNK) test at the 5\% significant level when the $F$ test was significant. For sensory acceptance analyses, the same model was used while also considering the session as a fixed effect and the panellist as a random effect.

\section{Results}

The genetic group (GG) did not affect any of studied traits except for the $\mathrm{pH}(P<0.007)$, where Angus bull $\times 1 / 2$ Simmental $+1 / 2$ Nellore cow (ANTS) showed the highest value (Fig. 1). Sex affected the $\mathrm{pH}(P<0.001)$, cooking loss (CL) $(P<0.001)$, water holding capacity (WHC) $(P<0.001)$ and shear force $(\mathrm{SF})(P<0.001)$ (Table 2). The production System (SYS) affected the flavour acceptance $(P<0.017)$, with feedlot-finished animals showing a higher value than pasture-fed animals (Fig. 2). A genetic group $(\mathrm{GG}) \times$ production system (SYS) interaction was found for the beef characteristic aroma (BCA) $(P=0.032)$, beef characteristic flavour (BCF) $(P=0.013)$, tenderness (TE) $(P=0.007)$, and texture acceptance $(P=0.001)$ sensory attributes (Table 3$)$. The production system $(\mathrm{SYS}) \times \operatorname{sex}(\mathrm{SEX})$ interaction was the major effect on many parameters, including the $\mathrm{L}^{*}$ meat $(P=0.015)$, $\mathrm{a}^{*}$ meat $(P=0.001), \mathrm{b} *$ meat $(P<0.001), \mathrm{L} *$ fat $(P=0.002)$, $\mathrm{a}^{*}$ fat $(P<0.001), \mathrm{b}^{*}$ fat $(P<0.001)$ and sensory acceptance attributes including the texture $(P<0.001)$ and overall acceptance $(P<0.001)$ (Table 4$)$. A triple interaction for sensory tenderness was found $(P=0.013)$ (Fig. 3$)$. The strange aroma

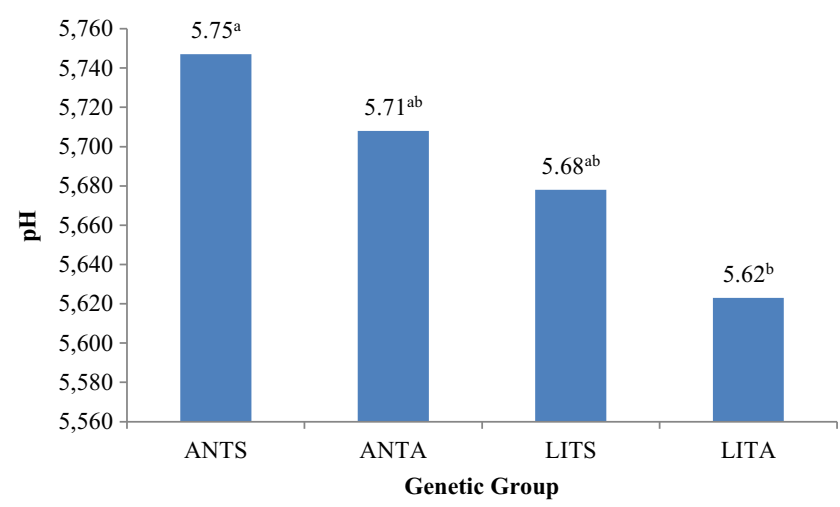

Fig. 1 Effect of the genetic group effect on the $\mathrm{pH}$. LITA = Limousin bull $\times 1 / 2$ Angus $+1 / 2$ Nellore cow; LITS $=$ Limousin bull $\times 1 / 2$ Simmental $+1 / 2$ Nellore cow; ANTA $=$ Angus bull $\times 1 / 2$ Angus $+1 / 2$ Nellore cow; ANTS $=$ Angus bull $\times 1 / 2$ Simmental $+1 / 2$ Nellore cow .

${ }^{\mathrm{a}, \mathrm{b}}$ Means with different superscripts are significantly different $(P<0.05)$

(SA) and strange flavour (SF) sensory attributes were not affected by any of the studied effects. For sensory acceptance, the consumers' profile was as follows: $59 \%$ female; $41 \%$ male; $80 \%$ between 18 and 35 years old; and $68 \%$ incomplete graduation. Flavour acceptance values ranged from 6.9 to 7.9 (like moderately to like very much); texture acceptance values ranged from 6.0 to 8.0 (like slightly to like very much) and overall acceptance values ranged from 6.4 to 8.0 (like slightly to like very much).

\section{Discussion}

The effect of sex on $\mathrm{pH}$ values can be related to pre-slaughter stress, which can be different between heifers and young bulls. Bulls are more stressed animals, and with glycogen depletion, the $\mathrm{pH}$ does not decrease as it does in heifers as showed in previous studies (Page et al. 2001; Weglarz 2010; Zhang et al. 2010). The $\mathrm{pH}$ difference also directly affects the water holding capacity (WHC) and cooking loss (CL). Meat with a lower $\mathrm{pH}$ value leads to a lower water holding capacity (WHC) and a higher cooking loss (CL), as can be observed in the obtained results (Table 2). The water holding capacity is linked to

Table 2 Effect of the sex on meat quality parameters

\begin{tabular}{lrrr}
\hline & \multicolumn{2}{c}{ Sex } & \multirow{2}{*}{$P$ value } \\
\cline { 2 - 3 } & \multicolumn{1}{c}{ Male } & Female & \\
\hline $\mathrm{pH}$ & $5.82 \mathrm{a}$ & $5.56 \mathrm{~b}$ & $<0.001$ \\
Cooking loss (\%) & $22.32 \mathrm{~b}$ & $23.24 \mathrm{a}$ & $<0.001$ \\
Water holding capacity (\%) & $79.03 \mathrm{a}$ & $75.11 \mathrm{~b}$ & $<0.001$ \\
Shear force (kgf) & $8.37 \mathrm{~b}$ & $9.39 \mathrm{a}$ & $<0.001$ \\
\hline
\end{tabular}

Means in the same line with different letters for each fixed effect are significantly different $(P<0.05)$ 


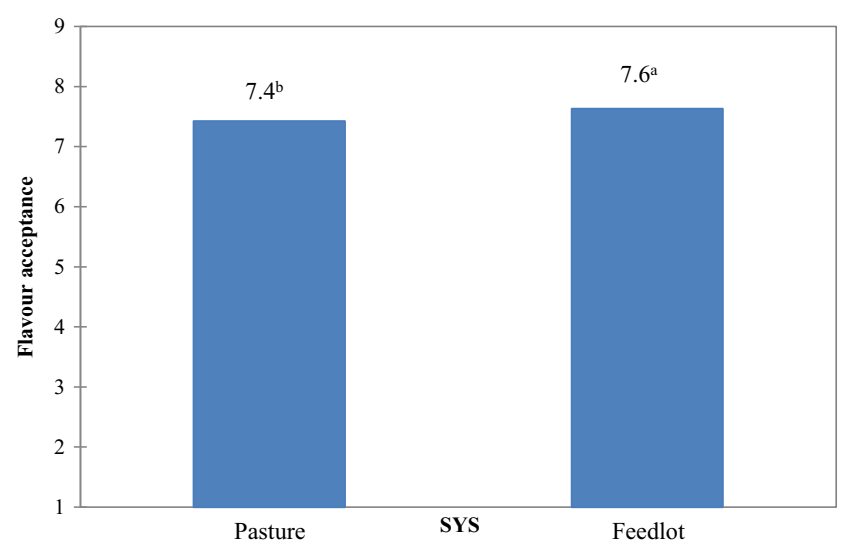

Fig. 2 Effect of the production system (SYS) on the flavour acceptance. ${ }^{\mathrm{a}, \mathrm{b}}$ Means with different superscripts are significantly different $(P<0.05)$

accelerated $\mathrm{pH}$ decline that can occur in stressed animals, leading to protein denaturation and consequently poor water binding ability (Huff-Lonergan and Lonergan 2005). All of the obtained values are within the expected values for $\mathrm{pH}$, water holding capacity (WHC) and cooking loss (CL) parameters. Regarding the shear force (SF), heifers showed less tender meat than young bulls. Sex affects muscle and fat depositions in the carcass (Choat et al. 2006; Panjono et al. 2009), but both values observed for tenderness in this study are considered high, as the established value for tender meat is less than $4.6 \mathrm{kgf}$ (Shackelford et al. 1991). Although in some studies (del Campo et al. 2008) it is reported that meat from animals finished on pasture was more tender than the meat from the ones finished on feedlot, this was not observed in this study. It is important to mention that pasture-finished animals were slaughtered older than feedlot-finished ones; if they were slaughtered at the same age, differences could have been found. Differences in carcass quality are reported among breed type but not for meat quality traits (Page et al. 2001); in this study, the values found for $\mathrm{pH}$ are within the expected range for beef (Fig. 1).

The production system (SYS) affected the flavour acceptance, as seen in Fig. 2. The production system or diet is one of the factors that can affect meat flavour, as the fatty acid composition and fat deposition vary, and they are precursors of volatile compounds (Larick and Turner 1990). In general, grass-fed (pasture) and grain-fed (feedlot) ruminant animals show different fatty acid profiles, which can lead to distinct flavours and off-flavours in the beef (Calkins and Hodgen 2007). In a previous study, beef from steers fed high-energy corn-containing diets for at least 90 days, compared with beef from pasture fed animals, usually had a more intense beefy flavour (Melton et al. 1982). A more intense flavour can result in a higher acceptance. Although there was a significant difference between the production systems, the scores are very similar and are between 7 and 8 for acceptance (like moderately and like very much, respectively).

An interaction between the genetic group $(\mathrm{GG}) \times$ production system (SYS) was found for the beef characteristic aroma (BCA), beef characteristic flavour, tenderness and texture acceptance (Table 3). The beef aroma and flavour are known to be affected by the breed of cattle. Nitrogen and sulphur compounds, free amino acids, alcohols, aldehydes and ketones in the flavour volatiles differ among beef from different breeds of cattle (Sato et al. 1995; Insausti et al. 2005). In the same production system, there was no effect among genetic groups regarding the beef characteristic aroma (BCA). Comparing the systems, a difference is found only for the Angus bull $\times 1 / 2$ Simmental $\times 1 / 2$ Nellore cow crossbreed (ANTS), where the BCA was significantly higher in the feedlot. For texture acceptance, the Limousin bull $\times 1 / 2$ Simmental $\times 1 / 2$ Nellore cow (LITS) and Limousin bull $\times 1 / 2$ Angus $\times 1 / 2$ Nellore cow (LITA) crossbreeds were different on pasture but not on feedlot. A significant difference between production systems for texture acceptance was found only for the Limousin bull $\times 1 / 2$ Simmental $\times 1 / 2$ Nellore cow (LITS) crossbreed, which showed the lowest acceptance score. Cattle finished on feedlot show faster growth rates compared to pasture-finished animals, and it is expected that the former ones produce more tender meat (Muir et al. 1998). In this study, the sensory tenderness was higher for some of the genetic groups on feedlot, but there was an interaction between the genetic groups and the production system.
Table 3 Interaction of the genetic group (GG) and production system (SYS) for sensory attributes

\begin{tabular}{|c|c|c|c|c|c|c|c|c|c|}
\hline \multirow[t]{2}{*}{ Sensory attribute } & \multicolumn{4}{|c|}{ Pasture } & \multicolumn{4}{|c|}{ Feedlot } & \multirow[t]{2}{*}{$P$ value } \\
\hline & LITA & LITS & ANTS & ANTA & LITA & LITS & ANTS & ANTA & \\
\hline BCA & $5.0 \mathrm{ab}$ & $4.3 \mathrm{ab}$ & $4.1 \mathrm{~b}$ & $4.4 \mathrm{ab}$ & $4.9 \mathrm{ab}$ & $5.2 \mathrm{a}$ & $5.1 \mathrm{a}$ & $5.1 \mathrm{a}$ & 0.032 \\
\hline $\mathrm{BCF}$ & $4.9 \mathrm{ab}$ & $4.5 \mathrm{ab}$ & $4.2 \mathrm{~b}$ & $4.3 \mathrm{ab}$ & $4.5 \mathrm{ab}$ & $4.7 \mathrm{ab}$ & $4.9 \mathrm{ab}$ & $5.1 \mathrm{a}$ & 0.013 \\
\hline $\mathrm{TE}$ & $5.8 \mathrm{ab}$ & $5.0 \mathrm{~b}$ & $5.7 \mathrm{ab}$ & $5.4 \mathrm{ab}$ & $5.5 \mathrm{ab}$ & $6.0 \mathrm{a}$ & $5.5 \mathrm{ab}$ & $5.1 \mathrm{ab}$ & 0.007 \\
\hline Texture acceptance & $7.5 \mathrm{ab}$ & $6.7 \mathrm{c}$ & $7.4 a b c$ & $7.1 \mathrm{bc}$ & $8.0 \mathrm{a}$ & $7.9 \mathrm{a}$ & $7.7 \mathrm{ab}$ & $7.1 \mathrm{bc}$ & 0.001 \\
\hline
\end{tabular}

Means in the same line with different letters are significantly different $(P<0.05)$. BCA $=$ beef characteristic aroma ( 1 = extremely bland; $9=$ extremely intense); $\mathrm{BCF}=$ beef characteristic flavour ( 1 = extremely bland; $9=$ extremely intense); TE $=$ tenderness $(1=$ extremely tough; $9=$ extremely tender $)$. LITA $=$ Limousin bull $\times 1 / 2$ Angus $+1 / 2$ Nellore cow LITS $=$ Limousin bull $\times 1 / 2$ Simmental $+1 / 2$ Nellore cow; ANTA $=$ Angus bull $\times 1 / 2$ Angus $+1 / 2$ Nellore cow; ANTS $=$ Angus bull $\times 1 / 2$ Simmental $+1 / 2$ Nellore cow 
Table 4 Interaction of the production system and sex for instrumental colour parameters and sensory acceptance values

\begin{tabular}{|c|c|c|c|c|c|}
\hline & \multicolumn{2}{|l|}{ Pasture } & \multicolumn{2}{|l|}{ Feedlot } & \multirow[t]{2}{*}{$P$ value } \\
\hline & Male & Female & Male & Female & \\
\hline $\mathrm{L}^{*}$ meat & $36.01 \mathrm{~b}$ & $36.1 \mathrm{~b}$ & $36.91 \mathrm{~b}$ & $38.60 \mathrm{a}$ & 0.015 \\
\hline$a^{*}$ meat & $14.44 \mathrm{a}$ & $14.59 \mathrm{a}$ & $13.22 \mathrm{~b}$ & $14.40 \mathrm{a}$ & 0.001 \\
\hline $\mathrm{b}^{*}$ meat & $11.86 \mathrm{~b}$ & $11.88 \mathrm{~b}$ & $11.25 \mathrm{~b}$ & $12.64 \mathrm{a}$ & $<0.001$ \\
\hline$L^{*}$ fat & $78.71 \mathrm{a}$ & $77.54 \mathrm{~b}$ & $77.04 \mathrm{~b}$ & $77.81 \mathrm{ab}$ & 0.002 \\
\hline$a^{*}$ fat & $6.07 \mathrm{~b}$ & $7.92 \mathrm{a}$ & $6.62 \mathrm{~b}$ & $6.22 b$ & $<0.001$ \\
\hline$b^{*}$ fat & $18.13 b$ & $22.53 \mathrm{a}$ & $15.11 \mathrm{c}$ & $16.21 \mathrm{c}$ & $<0.001$ \\
\hline Texture acceptance & $6.9 \mathrm{c}$ & $7.5 b$ & $8.0 \mathrm{a}$ & $7.3 b$ & $<0.001$ \\
\hline Overall acceptance & $7.0 \mathrm{c}$ & $7.6 \mathrm{ab}$ & $8.0 \mathrm{a}$ & $7.4 \mathrm{~b}$ & $<0.001$ \\
\hline
\end{tabular}

Means in the same line with different letters are significantly different $(P<0.05)$. Texture and overall acceptance: $1=$ dislike extremely; $9=$ like extremely

The meat and fat colour parameters as well as the sensory texture and overall acceptance attributes showed a production system $($ SYS $) \times \operatorname{sex}($ SEX) interaction (Table 4). For the colour $\left(\mathrm{L}^{*}, \mathrm{a}^{*}\right.$, and $\left.\mathrm{b}^{*}\right)$ parameters, there are differences between the sexes only for the feedlot but not for the pasture groups. Differences between systems (pasture and feedlot) depend on the sex. In a beef muscle colour survey, males showed higher colour parameters $\left(L^{*}, a^{*}\right.$, and $\left.b^{*}\right)$ than females (Page et al. 2001) even with no difference between their muscle $\mathrm{pH}$. In another study, the highest values for $\mathrm{a}^{*}$ and $\mathrm{b} *$ were found for bulls (Weglarz 2010). As the myoglobin concentration of muscle increases with age, it is expected that younger animals will have lighter and brighter meat (Muir et al. 1998). Pasturefinished animals were slaughtered 2 months after the feedlotfinished animals. All of these reported facts were not observed in this study due to the production system interaction with sex. The fat colour depends on age, sex, cattle breed and diet.
Animals finished on pasture generally show more yellow than those finished on feedlot, mainly due to the high concentration of carotenoids from green forage (Moloney et al. 2008; Dunne et al. 2009). The observed results are within the expected values, with higher values of fat colour for those animals finished on pasture than fat from feedlot-finished animals. As the human eye is not able to detect these differences, they will not probably be noticed by consumers.

For both sensory texture and overall acceptance attributes, young bulls (males) and heifers (females) showed significant differences within the production system. However, opposite acceptance scores are observed in the different systems. In pasture, heifers showed higher acceptance, but on feedlot, young bulls are the most accepted. Within each sex, young bulls showed higher texture and overall acceptance on feedlot than on pasture. On feedlot, young bulls have a different fat deposition, which can affect the tenderness. The overall acceptance is highly affected by the tenderness, as it is considered the most important attribute for beef sensory acceptance.

A triple interaction was observed for the tenderness (TE) sensory attribute (Fig. 3). On the same production system (pasture), a significant difference was observed for Limousin bull $\times 1 / 2$ Simmental $+1 / 2$ Nellore cow (LITS) and Limousin bull $\times 1 / 2$ Angus $+1 / 2$ Nellore cow (LITA) young bulls as well as for feedlot, but there was no difference among the studied genetic groups. Angus bull $\times 1 / 2$ Angus $+1 / 2$ Nellore cow (ANTA) heifers on feedlot and Limousin bull $\times$ $1 / 2$ Simmental $+1 / 2$ Nellore cow (LITS) young bulls showed the lowest scores for texture, while Limousin bull $\times 1 / 2$ Angus $\times 1 / 2$ Nellore cow (LITA) young bulls on pasture were considered more tender.

Differences between the production systems depended on the sex or genetic group combinations. For meat colour parameters, there are differences between sexes only for feedlotfinished animals, where females showed higher values than
Fig. 3 Triple interaction values for the sensory texture. $\mathrm{M}=$ male; $\mathrm{F}=$ female , LITA $=$ Limousin bull $\times 1 / 2$ Angus $+1 / 2$ Nellore cow; LITS $=$ Limousin bull $\times 1 / 2$ Simmental $+1 / 2$ Nellore cow; ANTA $=$ Angus bull $\times 1 / 2$ Angus $+1 / 2$ Nellore cow; ANTS $=$ Angus bull $\times 1 / 2$ Simmental $+1 / 2$ Nellore cow. ${ }^{\mathrm{a}, \mathrm{b}}$ Means with different superscripts are significantly different $(P<0.05)$

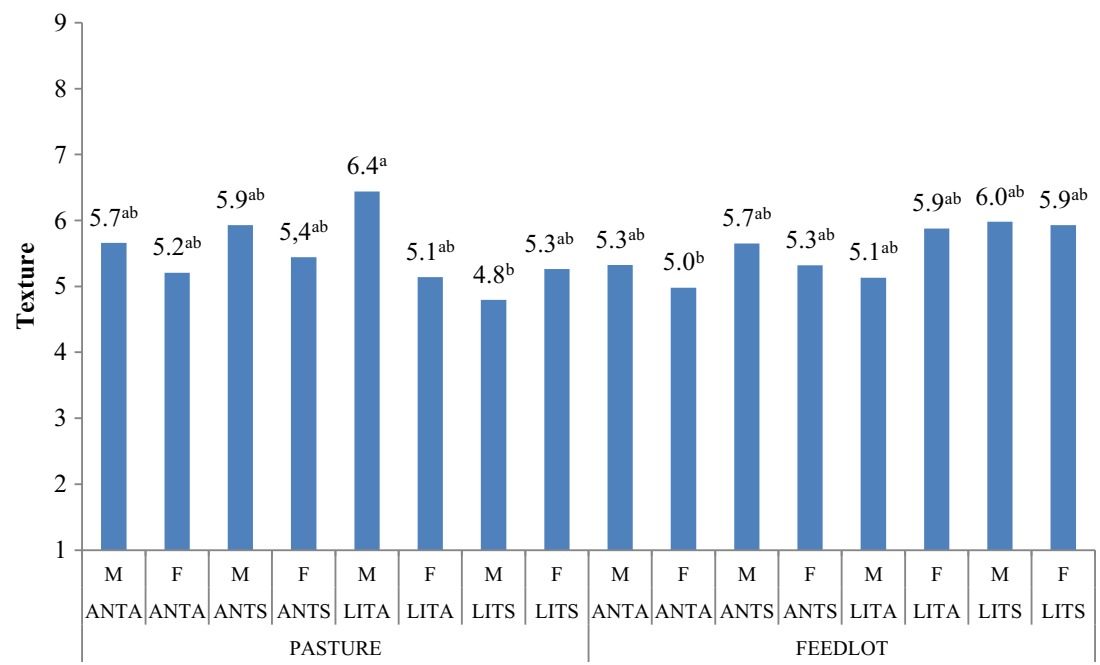

Treatments 
males. Pasture-finished females showed higher texture and overall acceptance than males, but the opposite occurred for feedlot-finished animals. Pasture-finished Limousin bull $\times 1 / 2$ Simmental $+1 / 2$ Nellore cow (LITS) animals showed lower texture acceptance than feedlot-finished ones.

Acknowledgements The authors acknowledge the financial support for this study from the National Council for Scientific and Technological Development (CNPq) process 472344/2012-9 and the Brazilian Agricultural Research Corporation (Embrapa), Brazil.

\section{Compliance with ethical standards}

Statement of animal and human rights All procedures performed in studies involving animals were in accordance with the ethical standards of the institution or practice at which the studies were conducted and were approved by the local Committee on Animal Research and Ethics, protocol number PRT 02/2015. All procedures performed in studies involving human participants were in accordance with the ethical standards of the institutional and/or national research committee and were approved by the Human Experiment Ethics Committee of Universidade Federal de São Carlos, Brazil, protocol number 322/2011. Informed consent was obtained from all individual participants included in the study.

Conflict of interest The authors declare that they have no conflict of interest.

\section{References}

Bernard, C., Cassar-Malek, I., Le Cunff, M., Dubroeucq, H., Renand, G. and Hocquette, J.-F., 2007. New Indicators of Beef Sensory Quality Revealed by Expression of Specific Genes, Journal of Agricultural and Food Chemistry, 55, 5229-5237

Calkins, C.R. and Hodgen, J.M., 2007. A fresh look at meat flavour, Meat Science, 77, 63-80

Choat, W.T., Paterson, J.A., Rainey, B.M., King, M.C., Smith, G.C., Belk, K.E. and Lipsey, R.J., 2006. The effects of cattle sex on carcass characteristics and longissimus muscle palatability, Journal of animal science, 84, 1820-1826

del Campo, M., Brito, G., de Lima, J.M.S., Martins, D.V., Sañudo, C., Julián, R.S., Hernández, P. and Montossi, F., 2008. Effects of feeding strategies including different proportion of pasture and concentrate, on carcass and meat quality traits in Uruguayan steers, Meat Science, 80, 753-760

Dunne, P.G., Monahan, F.J., O’Mara, F.P. and Moloney, A.P., 2009. Colour of bovine subcutaneous adipose tissue: A review of contributory factors, associations with carcass and meat quality and its potential utility in authentication of dietary history, Meat science, $81,28-45$
French, P., O’Riordan, E.G., Monahan, F.J., Caffrey, P.J., Mooney, M.T., Troy, D.J. and Moloney, A.P., 2001. The eating quality of meat of steers fed grass and/or concentrates, Meat Science, 57, 379-386

French, P., O'Riordan, E.G., Monahan, F.J., Caffrey, P.J., Vidal, M., Mooney, M.T., Troy, D.J. and Moloney, A.P., 2000. Meat quality of steers finished on autumn grass, grass silage or concentrate-based diets, Meat Science, 56, 173-180

Hamm, R., 1986. 4 - Functional Properties of the Myofibrillar System and Their Measurements In:, P. J. Bechtel (ed), Muscle As Food, (Academic Press: San Diego), 135-199

Huff-Lonergan, E. and Lonergan, S.M., 2005. Mechanisms of waterholding capacity of meat: The role of postmortem biochemical and structural changes, Meat Science, 71, 194-204

Insausti, K., Goni, V., Petri, E., Gorraiz, C. and Beriain, M.J., 2005. Effect of weight at slaughter on the volatile compounds of cooked beef from Spanish cattle breeds Meat science, 70, 83-90

Larick, D.K. and Turner, B.E., 1990. Headspace Volatiles and Sensory Characteristics of Ground Beef from Forage- and Grain-Fed Heifers, Journal of Food Science, 55, 649-654

Melton, S.L., Amiri, M., Davis, G.W. and Backus, W.R., 1982. Flavour and Chemical Characteristics of Ground Beef from Grass, ForageGrain- and Grain-Finished Steers, Journal of Animal Science, 55, $77-87$

Moloney, A.P., Keane, M.G., Dunne, P.G., Mooney, M.T. and Troy, D.J., 2008. Effect of concentrate feeding pattern in a grass silage/ concentrate beef finishing system on performance, selected carcass and meat quality characteristics, Meat Science, 79, 355-364

Muir, P.D., Deaker, J.M. and Bown, M.D., 1998. Effects of forage- and grain-based feeding systems on beef quality: A review New Zealand, Journal of Agricultural Research, 41, 623-635

Page, J.K., Wulf, D.M. and Schwotzer, T.R., 2001. A survey of beef muscle colour and $\mathrm{pH}$. Journal of animal science, 79, 678-687

Panjono, Kang, S.M., Lee, I.S. and Lee, S.K., 2009. Carcass characteristics of Hanwoo (Korean cattle) from different sex conditions, raising altitudes and slaughter seasons, Livestock Science, 123, 283-287

Realini, C.E., Duckett, S.K., Brito, G.W., Dalla Rizza, M. and De Mattos, D., 2004. Effect of pasture vs. concentrate feeding with or without antioxidants on carcass characteristics, fatty acid composition, and quality of Uruguayan beef, Meat Science, 66, 567-577

Sato, M., Nakamura, T., Numata, M., Kuwahara, K., Homma, S., Sato, A. and Fujimaki, M., 1995. Study on factors related to beef guality: On the flavour and umami taste of Japanese black cattle branded beef, Animal Science and Technology (Japan), 66, 274-282

Shackelford, S.D., Morgan, J.B., Cross, H.R. and Savell, J.W., 1991. Identification of threshold levels for warner-bratzler shear force in Beef top loin steaks, Journal of Muscle Foods, 2, 289-296

Varela, A., Oliete, B., Moreno, T., Portela, C., Monserrrat, L., Carballo, J.A. and Sánchez, L., 2004. Effect of pasture finishing on the meat characteristics and intramuscular fatty acid profile of steers of the Rubia Gallega breed, Meat Science, 67, 515-522

Węglarz, A., 2010. Quality of beef from semi-intensively fattened heifers and bulls, Animal science papers and reports, 28, 207-218

Zhang, Y., Zan, L., Wang, H., Xin, Y. and Adoligbe, C.M., 2010. Effect of sex on meat quality characteristics of Qinchuan cattle African, Journal of Biotechnology, 9, 4504-4509 